\title{
Article
}

\section{pH-Dependent Protein Binding Properties of Uremic Toxins In Vitro}

\author{
Suguru Yamamoto ${ }^{1, *(\mathbb{D}, \text { Kenichi Sasahara }}{ }^{2}$, Mio Domon ${ }^{1}$, Keiichi Yamaguchi ${ }^{2}$, Toru Ito ${ }^{1}$, Shin Goto ${ }^{1}$, Yuji Goto ${ }^{2}$ \\ and Ichiei Narita ${ }^{1}$
}

check for

updates

Citation: Yamamoto, S.; Sasahara, K.; Domon, M.; Yamaguchi, K.; Ito, T.; Goto, S.; Goto, Y.; Narita, I. pH-Dependent Protein Binding Properties of Uremic Toxins In Vitro. Toxins 2021, 13, 116. https:// doi.org/10.3390/toxins13020116

Received: 18 December 2020

Accepted: 1 February 2021

Published: 4 February 2021

Publisher's Note: MDPI stays neutral with regard to jurisdictional claims in published maps and institutional affiliations.

Copyright: (c) 2021 by the authors. Licensee MDPI, Basel, Switzerland. This article is an open access article distributed under the terms and conditions of the Creative Commons Attribution (CC BY) license (https:/ / creativecommons.org/licenses/by/ $4.0 /)$.
1 Division of Clinical Nephrology and Rheumatology, Niigata University Graduate School of Medical and Dental Sciences, Niigata 951-8510, Japan; mio.dmn@gmail.com (M.D.); itotoru.gt@gmail.com (T.I.); gotos@med.niigata-u.ac.jp (S.G.); naritai@med.niigata-u.ac.jp (I.N.)

2 Institute for Protein Research, Osaka University, Yamadaoka 3-2, Suita, Osaka 565-0871, Japan; ksasahara@protein.osaka-u.ac.jp (K.S.); kyamaguchi@protein.osaka-u.ac.jp (K.Y.); gtyj8126@protein.osaka-u.ac.jp (Y.G.)

* Correspondence: yamamots@med.niigata-u.ac.jp; Tel.: +81-25-227-2200

\begin{abstract}
Protein-bound uremic toxins (PBUTs) are difficult to remove using conventional dialysis treatment owing to their high protein-binding affinity. As $\mathrm{pH}$ changes the conformation of proteins, it may be associated with the binding of uremic toxins. Albumin conformation at $\mathrm{pH} 2$ to 13 was analyzed using circular dichroism. The protein binding behavior between indoxyl sulfate (IS) and albumin was examined using isothermal titration calorimetry. Albumin with IS, and serum with IS, p-cresyl sulfate, indole acetic acid or phenyl sulfate, as well as serum from hemodialysis patients, were adjusted $\mathrm{pH}$ of 3 to 11, and the concentration of the free PBUTs was measured using mass spectrometry. Albumin was unfolded at $\mathrm{pH}<4$ or $>12$, and weakened interaction with IS occurred at $\mathrm{pH}<5$ or $>10$. The concentration of free IS in the albumin solution was increased at $\mathrm{pH} 4.0$ and $\mathrm{pH}$ 11.0. Addition of human serum to each toxin resulted in increased free forms at acidic and alkaline $\mathrm{pH}$. The $\mathrm{pH}$ values of serums from patients undergoing hemodialysis adjusted to 3.4 and 11.3 resulted in increased concentrations of the free forms of PBUTs. In conclusion, acidic and alkaline $\mathrm{pH}$ conditions changed the albumin conformation and weakened the protein binding property of PBUTs in vitro.
\end{abstract}

Keywords: $\mathrm{pH}$; uremic toxins; albumin; indoxyl sulfate; isothermal titration calorimetry

Key Contribution: Acidic and alkaline $\mathrm{pH}$ conditions weakened the protein binding property of PBUTs with changes in the conformation of proteins. Modification of dialysis treatment through some external stimulations while blood passes through the dialyzer column to increase the removal of free uremic toxins is a crucial step to achieving improved clinical outcomes in patients undergoing dialysis treatment.

\section{Introduction}

Patients with chronic kidney disease (CKD) undergoing dialysis treatment have worse clinical outcomes owing to various systemic disorders including cardiovascular disease, mineral and bone disorders, and infectious disease. One of the reasons underlying the development of these outcomes is the direct or indirect interactions between various uremic toxins and organ/tissues [1-4]. Among them, several solutes, such as indoxyl sulfate (IS) and p-cresyl sulfate (PCS), bind easily to large proteins including albumin and are called protein-bound uremic toxins (PBUTs) [5]. Basic and clinical studies have demonstrated the strong toxicities of PBUTs which are associated with systemic disorders [1-4]; however, these solutes are difficult to remove with conventional hemodialysis treatment owing to their high protein binding property [6]. Thus, the development of a method that increases the removal of PBUTs should be the most fundamental approach to improving clinical 
outcomes in patients undergoing dialysis. One of the possible therapeutic strategies will be to weaken the binding property of PBUTs because the increase in the free form of uremic toxins will facilitate the removal through dialysis treatment.

Previous basic studies have identified the uremic toxin-binding site of albumin in vitro [7-10]. Albumin molecules change their conformations with the change of $\mathrm{pH}$ in the solution $[8,11,12]$. Thus, the $\mathrm{pH}$-induced conformational change of proteins may be associated with the binding property of PBUTs. In this study, we examined the protein-binding properties of uremic toxins with $\mathrm{pH}$ changes in vitro.

\section{Results}

\subsection{Conformational Change of Albumin Depending on the $p H$ of Solutions}

To gain insight into the $\mathrm{pH}$-dependent conformational change of albumin, we measured Circular dichroism (CD) spectra at various $\mathrm{pH}$ conditions. At around neutral $\mathrm{pH}$, CD spectra exhibited double minima at $208 \mathrm{~nm}$ and $222 \mathrm{~nm}$ (Figure 1A,B), indicating that albumin had an $\alpha$-helical conformation. We then plotted the ellipticities at $222 \mathrm{~nm}$ (Figure 1C), which were correlated with the $\alpha$-helical content of albumin and the $\mathrm{pH}$ of the solutions. The ellipticities of CD spectra decreased under both acidic and alkaline $\mathrm{pH}$ conditions, indicating that albumin unfolded at $\mathrm{pH}$ below 5 or above 12, as observed previously [12].
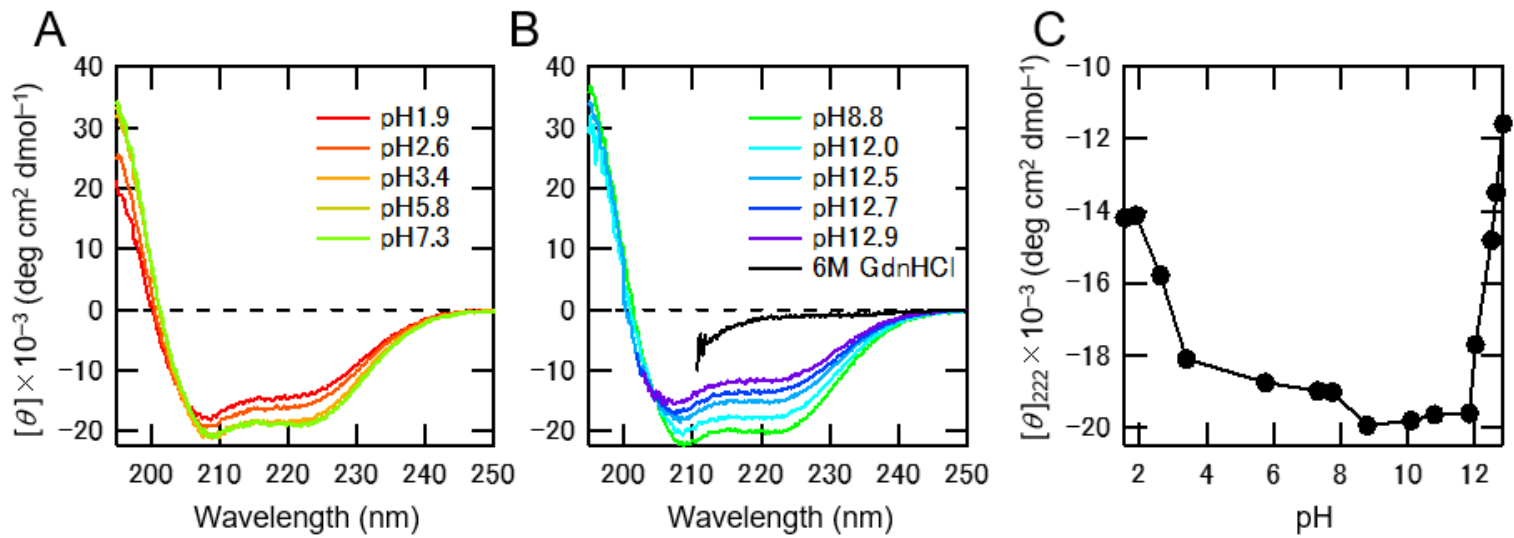

Figure 1. $\mathrm{pH}$-dependent conformational change of albumin. Representative Circular dichroism (CD) spectra of albumin in acidic $\mathrm{pH}(\mathbf{A})$ and basic $\mathrm{pH}(\mathbf{B})$ regions. The $\mathrm{pH}$ of solutions is indicated within the figures. The spectrum of completely unfolded albumin in $6 \mathrm{M} \mathrm{GdnHCl}$ is indicated as a black line (B). (C) The ellipticities of CD spectra measured at $222 \mathrm{~nm}$ are plotted against the $\mathrm{pH}$ of the solutions.

\subsection{Interaction between IS and Albumin Depending on the $p H$ of the Solution}

To examine the affinity between IS and albumin, we performed Isothermal Titration Calorimetry (ITC) experiments under various $\mathrm{pH}$ conditions. Negative peaks resulting from the reaction indicated the exothermic nature of the binding process (Figure $2 \mathrm{~A}-\mathrm{C}$ ). At $\mathrm{pH} 7.6$, the titration of IS with albumin showed a saturation curve (Figure 2B), with the strength of the interaction at $\mathrm{pH} 7.6$ being stronger than that at $\mathrm{pH} 4.4$ (Figure 2A) and pH 10.6 (Figure 2C). Complete saturations were achieved at a molar ratio of $>1$ under all conditions. The enthalpy change $(\Delta H)$, entropy change $(-T \Delta S)$, and free energy change $(\Delta G)$ for binding were plotted against the $\mathrm{pH}$ of the solutions (Figure 2D). The value of $\Delta H$ negatively correlated with the $\mathrm{pH}$ of the solution, where negatively charged IS could interact with positively charged albumin (isoelectric point of albumin was 4.7). However, the $\Delta G$ that resulted from the sum of $\Delta H$ and $-T \Delta S$ decreased at neutral $\mathrm{pH}$. We then plotted the dissociation constants $\left(K_{\mathrm{D}}\right)$ against the $\mathrm{pH}$ of the solutions (Figure $2 \mathrm{E}$ ). Although the $K_{\mathrm{D}}$ was less than $10 \mu \mathrm{M}$ at neutral $\mathrm{pH}$, it significantly increased at a $\mathrm{pH}$ lower than 5 or higher than 10 . These $\mathrm{pH}$ regions $(\mathrm{pH}<5$ or $>10$ ) were almost consistent with the partially 
unfolded albumin in the CD experiments, indicating that the interaction between IS and albumin was weakened by the partially unfolded albumin.
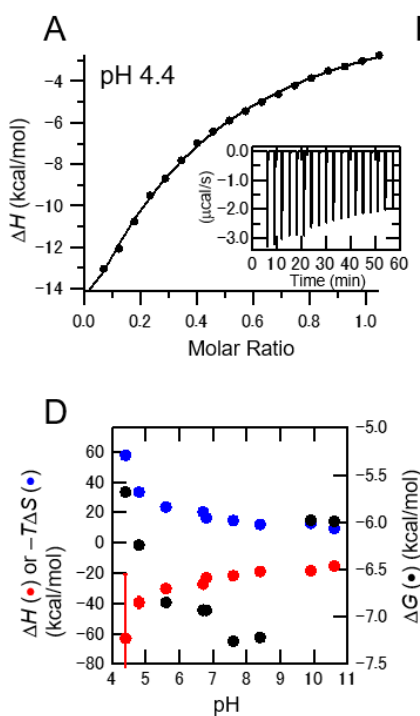

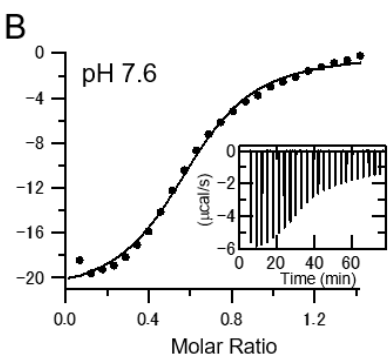

E

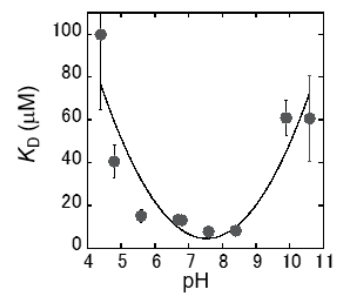

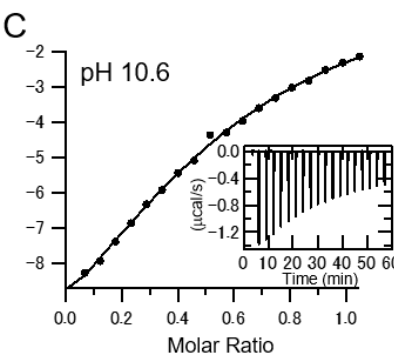

$\mathrm{F}$

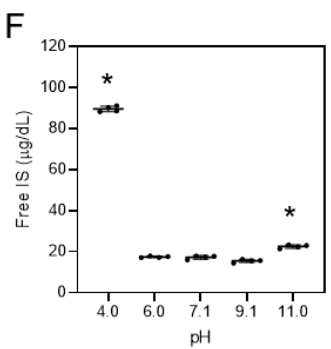

Figure 2. Interaction between indoxyl sulfate (IS) and albumin as monitored using Isothermal Titration Calorimetry. (A-C) Total enthalpy change $(\Delta H)$ for each injection at $\mathrm{pH} 4.4(\mathbf{A}), 7.6(\mathbf{B})$, and 10.6 (C). Insets show the direct enthalpy change resulting from the addition of IS to $150 \mu \mathrm{M}$ albumin. (D, E) Thermodynamic parameters $(\Delta H$ (red), $-T \Delta S$ (blue), and $\Delta G$ (black)) (D) and dissociation constant $\left(K_{\mathrm{D}}\right)(\mathrm{E})$ are plotted against $\mathrm{pH}$ of solutions. (F) Protein-unbound IS at $\mathrm{pH} 4-11$ in the presence of albumin. $\mathrm{pH}$ of albumin solution ( $3 \mathrm{~g} / \mathrm{dL}$ ) adjusted to 4.0, 6.0, 7.1, 9.1, and 11.0, and IS $(2 \mathrm{mg} / \mathrm{dL}$ ) was added to each albumin solution and the concentrations of free-form IS were measured. Data are shown as the mean \pm standard deviation of four independent experiments. ${ }^{*} p<0.01$ vs. $\mathrm{pH} 7.1$.

The $\mathrm{pH}$ of human serum albumin solution $(3 \mathrm{mg} / \mathrm{dL}$ ) was adjusted to $4.0-11.0$, and IS at a concentration of $2 \mathrm{mg} / \mathrm{dL}$ was added to reveal the protein-binding property of IS for various $\mathrm{pH}$ conditions. It was observed that the same concentration of total IS was present in all the solutions. (Figure S1A). The concentration of free IS significantly increased at $\mathrm{pH}$ 4.0 and $\mathrm{pH} 11.0(\mathrm{pH} 4.0: 89.49 \pm 1.38 \mu \mathrm{g} / \mathrm{dL}$ and $\mathrm{pH}$ 11.0: $22.45 \pm 1.38 \mu \mathrm{g} / \mathrm{dL}$ vs. $\mathrm{pH} 7.1$ : $17.20 \pm 0.87 \mu \mathrm{g} / \mathrm{dL}, p<0.01$, respectively, Figure $2 \mathrm{~F}$ and Table S1). These results suggest that acidic and alkaline $\mathrm{pH}$ conditions weakened the interaction between IS and albumin.

\section{3. $p H$-Dependent Protein-Binding Property of Uremic Toxins in Serum}

When human serum from non-CKD patients adjusted from $\mathrm{pH} 3.2$ to 11.0 was added to the IS at a concentration typically found in dialysis patients (Figure S2A), the concentrations of the free form of the IS in the serum under acidic and alkaline $\mathrm{pH}$ conditions was higher than that in serum at a neutral $\mathrm{pH}(\mathrm{pH} 3.2: 403.3 \pm 16.7 \mu \mathrm{g} / \mathrm{dL}, \mathrm{pH}$ 9.2: $220.0 \pm 1.0 \mu \mathrm{g} / \mathrm{dL}$, $\mathrm{pH}$ 10.0: $307.0 \pm 7.9 \mu \mathrm{g} / \mathrm{dL}, \mathrm{pH} 11.0: 567.4 \pm 28.6 \mu \mathrm{g} / \mathrm{dL}$ vs. $\mathrm{pH} 7.1: 134.7 \pm 3.5 \mu \mathrm{g} / \mathrm{dL}$, $p<0.01$, Figure 3A and Table S2). When PCS, indole acetic acid (IAA), and phenyl sulfate $(\mathrm{PhS})$ were reacted with serum from non-CKD patients under various $\mathrm{pH}$ conditions, the same trends were observed (Figure 3B-D and Figure S2B-D, and Table S2). 


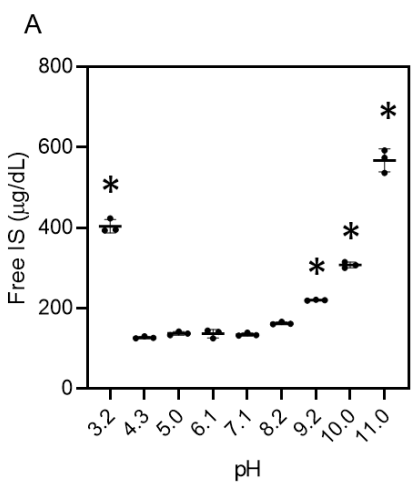

C

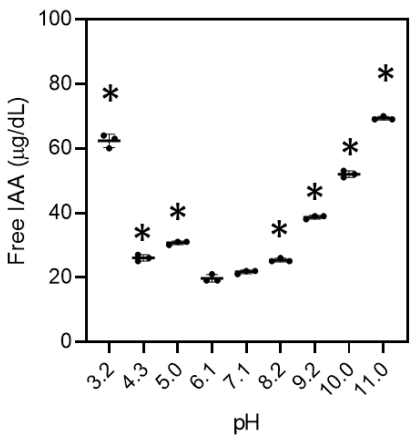

B

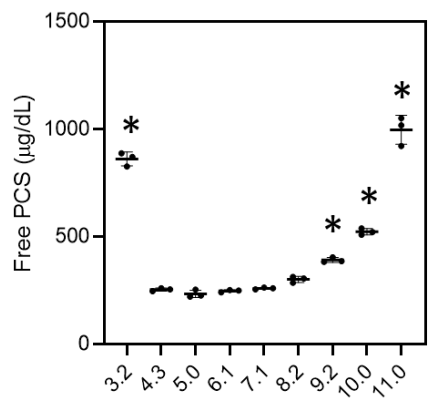

$\mathrm{pH}$

D

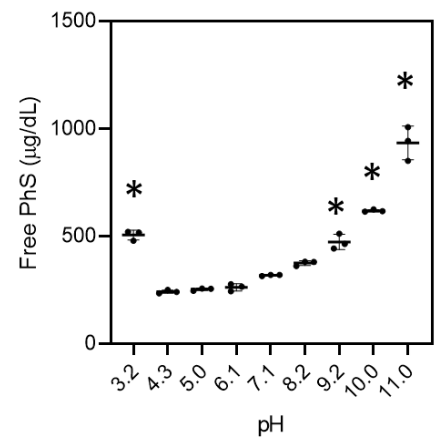

Figure 3. Protein-unbound uremic toxins at $\mathrm{pH} 3.2-11.0$ in human serum. Human serum from non-chronic kidney disease patients containing indoxyl sulfate (IS) (A), p-cresyl sulfate (PCS) (B), indole acetic acid (IAA) (C), or phenyl sulfate (PhS) (D) at the typical concentrations of patients undergoing dialysis was adjusted $\mathrm{pH}$ from 3.2 to 11.0. The concentrations of free-form uremic toxins were measured. Data are shown as the mean \pm standard deviation of three independent experiments. ${ }^{*} p<0.01$ vs. $\mathrm{pH} 7.1$.

The protein-binding property of uremic toxins in serum from patients undergoing dialysis was also assessed under various $\mathrm{pH}$ conditions. Table S3 shows the data of 19 patients undergoing maintenance hemodialysis which are typical characteristics of patients with CKD undergoing dialysis treatment. The $\mathrm{pH}$ of serum not adjusted with the buffer was $7.9 \pm 0.1$. The $\mathrm{pH}$ of serum from the patients was adjusted from 3.4 to 11.3 with the buffer, with the same volume with serum, which showed the same concentrations of total uremic toxins in all the solutions (Figure S3A,C,E,G). The concentrations of the free forms of IS, PCS, PhS, and IAA increased under acidic and alkaline pH conditions (e.g., IS: $\mathrm{pH}$ 3.4, $152.5 \pm 77.6 \mu \mathrm{g} / \mathrm{dL} ; \mathrm{pH} 11.3,153.8 \pm 135.5 \mu \mathrm{g} / \mathrm{dL}$ vs. $\mathrm{pH} 8.4,38.8 \pm 33.4 \mu \mathrm{g} / \mathrm{dL} ; p<0.01$, Figure 4 and Table S4) as well as the protein-bound rate (e.g., IS: $\mathrm{pH} 3.4,83.3 \pm 5.4 \%$; $\mathrm{pH}$ $11.3,84.3 \pm 11.7 \%$ vs. $\mathrm{pH} 8.4,96.5 \pm 2.4 \%$; $p<0.01$, Figure S3B,D,F,H). We also examined $\mathrm{pH}$-induced protein-bound properties of hippuric acid (HA) and creatinine, which are known to have lower protein-binding properties than IS, PCS, PhS, and IAA. As expected, the acidic and alkaline $\mathrm{pH}$ did not change the concentration (Figure S4).

These results suggest that acidic and alkaline $\mathrm{pH}$ conditions increased the free form of uremic toxins in serum and simultaneously weakened the protein-binding properties of PBUTs. 


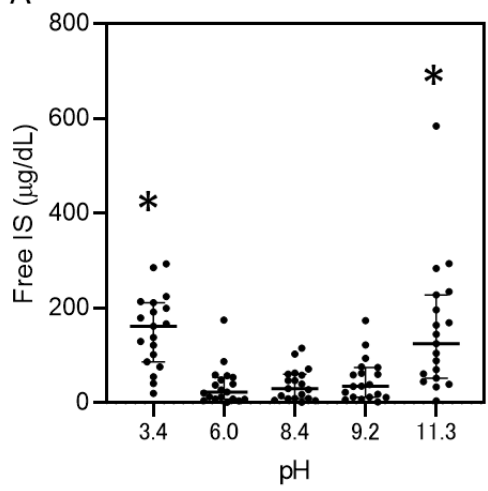

C

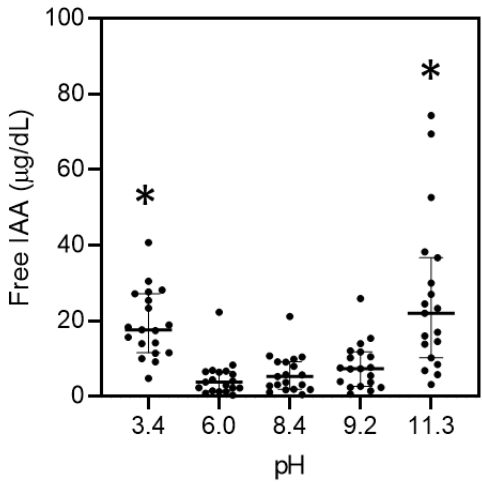

B

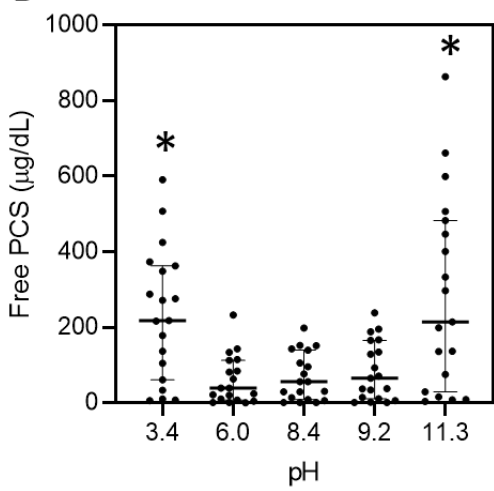

D

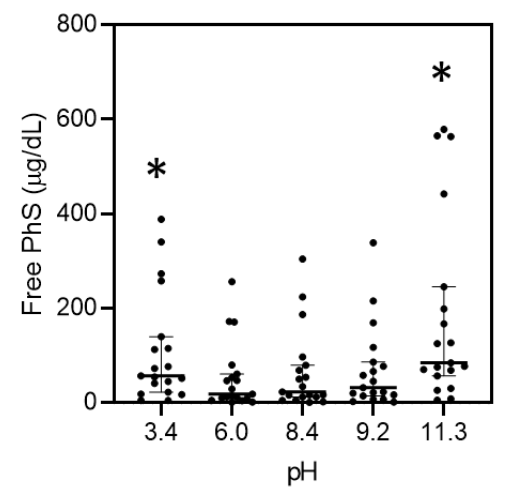

Figure 4. Protein-unbound uremic toxins at $\mathrm{pH} 3.4-11.3$ in serum specimens from patients undergoing hemodialysis treatment. Serum levels of free indoxyl sulfate (IS) (A), p-cresyl sulfate (PCS) (B), indole acetic acid (IAA) (C), or phenyl sulfate (PhS) (D) at each $\mathrm{pH}$ were measured. Data are expressed as the median values (interquartile range) of 19 individuals. ${ }^{*} p<0.01$ vs. $\mathrm{pH} 8.4$.

\section{Discussion}

In this study, we showed that acidic and alkaline $\mathrm{pH}$ conditions weakened the proteinbinding affinity of PBUTs in vitro. One of the key factors for the reduced binding affinities of PBUTs is the $\mathrm{pH}$-induced conformational change of proteins.

Removal of PBUTs using conventional dialysis treatment is insufficient. For example, circulating IS and PCS show a high protein-bound rate (97.7\% and $95.1 \%)$, with reduction rates of merely $31.8 \%$ and $29.1 \%$, respectively, using standard hemodialysis [6]. Several studies have suggested that direct hemoperfusion using activated carbon [13], oral charcoal administration [14] as well as adding activated charcoal into the dialysate [15] are able to reduce the serum level of PBUTs, and the adsorption method may be one of the attractive strategies to remove PBUTs. Another possible mechanism is through increasing the free PBUTs with weakened protein-binding property. Previous studies have detected binding sites (sites 1 and 2) in albumin for several uremic toxins [7-10,16,17], and IS and PCS are known to be competitive binding inhibitors because the binding site of albumin is the same for both substances [18]. In this study, our focus was on the effect of $\mathrm{pH}$ conditions on the conformational changes in proteins. In fact, acidic and alkaline $\mathrm{pH}$ conditions induced the conformational change of albumin toward unfolded (Figure 1), and such $\mathrm{pH}$ conditions weakened the binding property of albumin with IS (Figure 2). Since the pH-induced conformational change of albumin corresponds to the increase in free-form uremic toxins, the affinity of albumin binding sites to uremic toxins also weakened. The same results were observed in the serum from non-CKD patients with uremic toxins as well as the serum from patients undergoing hemodialysis treatment (Figures 3 and 4) which contained various kinds of proteins. These data suggest that several kinds of uremic toxins bind to proteins ubiquitously, and their affinities are affected by $\mathrm{pH}$ conditions in the serum owing to the conformational change of the proteins. In the calorimetric analysis shown 
in Figure 2, albumin with conformational abnormalities at acidic and alkaline $\mathrm{pH}$ values interacted less with IS in vitro than the other substance. In contrast, when the $\mathrm{pH}$ of the uremic serum changed under acidic and alkaline conditions, uremic toxins were separated from the proteins (Figure 4). These results suggest that conformational changes in albumin at acidic and alkaline $\mathrm{pH}$ are associated with both binding and dissociation with uremic toxins. In our study, the data showed different trends for the protein-biding properties for uremic toxins between the albumin solution (Figure 2F), non-CKD serum (Figure 3), and uremic serum (Figure 4). For example, the free IS level in non-CKD serum at $\mathrm{pH}$ 4.3 was not higher than that at $\mathrm{pH} 7.1$ (Figure $3 \mathrm{~A}$ ) while albumin at $\mathrm{pH} 4.0$ showed less protein-binding property with IS than that at $\mathrm{pH} 7.1$ (Figure 2F). This discrepancy may be induced with the difference of setting between the albumin solution and serum containing various kinds of proteins. Another possibility may be the effect of the isoelectoric point of albumin ( $\mathrm{pH}$ 4.7) on the protein-binding property with uremic toxins. It may enhance the interaction with uremic toxins even when the protein conformation was changed at acidic $\mathrm{pH}$. In this study, PhS showed the weakest reaction for the $\mathrm{pH}$-induced binding ability compared to other PBUTs (Figure 4). Previous studies have suggested that IS, IAA, and PCS bound to site 2 in the albumin via hydrogen bonds [9,17], while little information is reported for PhS. Thus, the binding site of PhS, or the intermolecular bonding interaction may be different with other uremic toxins. Further studies are needed to elucidate the detailed characteristics of each uremic toxin for its respective protein-binding properties. Our calorimetric analysis (Figure 2) suggested that the binding of albumin to IS was dosedependent and that the binding of IS to albumin was the same at both low and high doses. These data suggest that low concentrations of IS in early-stage CKD patients show the same trend of protein-binding affinity as that in end-stage kidney disease patients. Albumin in the blood combines with not only uremic toxins but also with various molecules, such as drugs and fatty acids, and the changing conformation of protein should be considered in pharmacological effects in clinical use.

This is an in vitro study, but the insights gained may lead to the development of urgently needed therapeutic strategies to increase the removal of PBUTs in dialysis treatment. When the $\mathrm{pH}$ conditions of blood are modified through some external stimulations while passing through the dialyzer column, increased removal of free uremic toxins could be achieved using a diffusion/convection method. In a basic study, pigs with hepatic injury and sepsis were treated with a blood purification system using circulating albumin dialysate [19]. Before the albumin dialysate reached the filters, acid $(\mathrm{HCl})$ or base $(\mathrm{NaOH})$ was added for toxin removal from albumin. These systems may be more effective in increasing the removal of PBUTs in hemodialysis patients if huge changes in the $\mathrm{pH}$ of serum during passing through the dialyzer column can be realized. There are limitations to apply our data to the current clinical dialysis treatment because huge $\mathrm{pH}$ changes in human serum are reported only in vitro study [20], not in a clinical study. However, we would like to emphasize the importance of conformational changes of proteins to weaken their binding properties for uremic toxins using not only changing $\mathrm{pH}$ but other methods. We believe protein conformational change will be one of important concepts to increase the removal of uremic toxins with blood purification treatment which will lead to better clinical outcomes in patients undergoing dialysis treatment.

\section{Conclusions}

Both acidic and alkaline $\mathrm{pH}$ conditions could change the conformation of albumin and increase the amount of free PBUTs in vitro. A weakened protein bound property of PBUTs may increase the removal with hemodialysis treatment, and the modification of protein conformation is one of the effective strategies. The maintenance of a low level of PBUTs with some interventions for protein conformational change will improve clinical outcomes in end-stage kidney disease patients. 


\section{Materials and Methods}

\subsection{Measurement of Albumin}

CD spectra were recorded with a Jasco spectropolarimeter J-820 (Jasco Co., Ltd., Tokyo, Japan) using a quartz cell with a light path of $1 \mathrm{~mm}$ and a protein concentration of $2 \mu \mathrm{M}$ at $25^{\circ} \mathrm{C}$. The $\mathrm{pH}$ of the solution was adjusted using $\mathrm{HCl}$ or $\mathrm{NaOH}$. The results were expressed as the mean residue ellipticity $[\theta]\left(\mathrm{deg} \mathrm{cm}^{2} / \mathrm{dmol}\right)$.

\subsection{Interaction between Albumin and Indoxyl Sulfate Monitored by ITC}

ITC measurements were performed using a PEAQ-ITC instrument $\left(\right.$ MicroCal $^{\mathrm{TM}}$, Malvern Instruments, Malvern, UK) at various $\mathrm{pH}$ conditions and $37^{\circ} \mathrm{C}$. The $\mathrm{pH}$ of the solution was adjusted using $\mathrm{HCl}$ or $\mathrm{NaOH}$. IS $(1.1 \mathrm{mM})$ in the syringe was titrated into $150 \mu \mathrm{M}$ of human serum albumin (Sigma-Aldrich Co. St. Louis, MO, USA) in the ITC cell. ITC data were analyzed using Origin software (OriginLab Co., Ltd., Northampton, $\mathrm{MO}, \mathrm{USA})$.

\subsection{Reaction of Albumin with Indoxyl Sulfate under Changing $p H$}

The $\mathrm{pH}$ of human serum albumin (3 g/dL) in PBS was adjusted to 4.0, 6.0, 7.1, 9.1, and 11.0 using $\mathrm{HCl}$ or $\mathrm{NaOH}$. IS ( $2 \mathrm{mg} / \mathrm{dL}$ ) (Sigma-Aldrich) in PBS was added to the albumin solutions at each $\mathrm{pH}$, and the mixtures were incubated at $37^{\circ} \mathrm{C}$ for $30 \mathrm{~min}$. Concentrations of free and total form IS were measured.

\subsection{Reaction of Uremic Toxins and Serum from Normal Subjects with Changing $p H$}

IS was added to human serum from non-CKD patients (Cosmo Bio Co., Ltd., Tokyo, Japan) at a concentration of $3.74 \pm 0.08 \mathrm{mg} / \mathrm{dL}$, which is typical of dialysis patients [6]. The $\mathrm{pH}$ of the serum containing IS was adjusted to 3.2, 4.3, 5.0, 6.1, 7.1, 8.2, 9.2, 10.0, and 11.0 by adding phosphoric acid or $\mathrm{NaOH}$ to the same volume of buffer. Concentrations of free and total IS were measured. The same procedures were repeated for PCS $(3.64 \pm 0.05 \mathrm{mg} / \mathrm{dL})$ (Eiweiss Chemical Co. Ltd., Shizuoka, Japan), IAA (0.153 $\pm 0.004 \mathrm{mg} / \mathrm{dL})$ (Tokyo Chemical Industry Co., Ltd., Tokyo, Japan), and PhS (1.35 $\pm 0.02 \mathrm{mg} / \mathrm{dL})$ (Kureha Co., Ltd., Tokyo, Japan).

\subsection{Uremic Serum from Patients with Changing $p H$}

We recruited 19 patients undergoing maintenance hemodialysis treatment who had no residual kidney function from a single dialysis unit. All eligible patients received $4-5 \mathrm{~h}$ of hemodialysis thrice weekly using standard bicarbonate dialysate $\left(\mathrm{Na}^{+}: 140 \mathrm{mEq} / \mathrm{L}, \mathrm{K}^{+}\right.$: $\left.2.0 \mathrm{mEq} / \mathrm{L}, \mathrm{Ca}^{2+}: 2.75 \mathrm{mEq} / \mathrm{L}, \mathrm{Mg}^{2+}: 1.0 \mathrm{mEq} / \mathrm{L}, \mathrm{Cl}^{-}: 112.25 \mathrm{mEq} / \mathrm{L}, \mathrm{HCO}_{3}{ }^{-} 27.5 \mathrm{mEq} / \mathrm{L}\right)$ and 1.6-2.1 $\mathrm{m}^{2}$ dialyzers with synthetic membranes, polysulfone or polyethersulfone. The flow rates for blood and the dialysate were set at $180-250 \mathrm{~mL} / \mathrm{min}$ and $500 \mathrm{~mL} / \mathrm{min}$, respectively. Dialysis adequacy was estimated by using $\mathrm{Kt} / \mathrm{V}_{\text {urea }}$. Serum specimens at predialysis treatment were collected and immediately frozen at $-30{ }^{\circ} \mathrm{C}$ and thawed just before adjusting the $\mathrm{pH}$. The $\mathrm{pH}$ of uremic serum from each patient was adjusted to $3.4 \pm 0.2$, $6.0 \pm 0.2,8.4 \pm 0.2,9.2 \pm 0.2$, and $11.3 \pm 0.2$ using the same volume of buffer ( $\times 2$ dilution), and the mixtures were incubated at $37^{\circ} \mathrm{C}$ for $30 \mathrm{~min}$. Concentrations of uremic toxins in free and total forms were measured. This study adhered to the guidelines of the Declaration of Helsinki and was approved by the Central Ethics Committee at Niigata University (No. 2019-0060, date: 5 June 2019). It has been registered at the University Hospital Medical Information Network Center (UMIN000040111). All participants provided written informed consent.

\subsection{Measurement of Uremic Toxins}

Serum specimens collected from patients and the reaction solutions were immediately frozen at $-30{ }^{\circ} \mathrm{C}$ and thawed just before the measurement of PBUTs. Respective levels of total and free forms of four PBUTs such as IS, PCS, IAA, and PhS were measured using mass spectrometry as described previously [6]. 


\subsection{Statistical Analysis}

The data for the reaction between albumin/human serum and uremic toxins were expressed as the mean \pm standard deviation. One-way analysis of variance followed by Bonferroni's multiple comparisons test was used to compare the differences between the groups. Data for the uremic toxins at $\mathrm{pH}$ 3.4-11.3 were expressed as medians (interquartile range). Friedman's test was used to compare the differences between data at $\mathrm{pH} 8.4$ and those at $\mathrm{pH} 3.4,6.0,9.2$, and 11.3. The number of biological samples for each group is stated in the corresponding figure legends. Differences were considered statistically significant if the $p$-value was $<0.05$.

Supplementary Materials: The following are available online at https://www.mdpi.com/2072-6 651/13/2/116/s1, Table S1: Concentration of free IS in albumin solution at $\mathrm{pH}$ 4.0-11.0. Table S2: Concentrations of free IS, PCS, IAA, and PhS in non-CKD serum at pH 3.2-11.0. Table S3: Demographic and clinical characteristics, Table S4: Concentrations of free IS, PCS, IAA, and PhS in uremic serum at $\mathrm{pH}$ 3.4-11.3. Figure S1: Protein-unbound and -bound indoxyl sulfate at $\mathrm{pH} 4.0-11.0$ in the presence of albumin, Figure S2: Protein-unbound and -bound uremic toxins at pH 3.2-11.0 in human non-CKD serum, Figure S3. Protein-unbound and -bound uremic toxins and protein-bound rates at $\mathrm{pH}$ 3.4-11.3 in serum from patients undergoing hemodialysis. Figure S4. Serum level of HA and creatinine before and after ultracentrifugation at $\mathrm{pH}$ 3.4-11.3.

Author Contributions: Conception, study design, and interpretation of the data were performed by S.Y., K.S., K.Y., S.G., Y.G., and I.N. Measurement and analysis were performed by S.Y., K.S., M.D., K.Y., and T.I. The manuscript was drafted by S.Y., K.S., K.Y., S.G., Y.G., and I.N. All authors have read and agreed to the published version of the manuscript.

Funding: There is none to be declared.

Institutional Review Board Statement: The study was conducted according to the guidelines of the Declaration of Helsinki, and approved by the Central Ethics Committee at Niigata University (No. 2019-0060, date: 5 June 2019). It has been registered at the University Hospital Medical Information Network Center (UMIN000040111).

Informed Consent Statement: Informed consent was obtained from all subjects involved in the study.

Data Availability Statement: Data are available upon request, please contact the contributing authors.

Acknowledgments: The authors thank Kureha Corp. for excellent technical assistance.

Conflicts of Interest: This study was a joint research project with Kureha Corporation and Niigata University. Kureha Corporation provided technical support for the measurement of PBUT concentrations. Besides that, the authors declare no other potential competing financial interests.

\section{References}

1. Lekawanvijit, S.; Kompa, A.R.; Wang, B.H.; Kelly, D.J.; Krum, H. Cardiorenal syndrome: The emerging role of protein-bound uremic toxins. Circ. Res. 2012, 111, 1470-1483. [CrossRef]

2. Assem, M.; Lando, M.; Grissi, M.; Kamel, S.; Massy, Z.A.; Chillon, J.-M.; Hénaut, L. The impact of uremic toxins on cerebrovascular and cognitive disorders. Toxins 2018, 10, 303. [CrossRef]

3. Barreto, F.C.; Barreto, D.V.; Liabeuf, S.; Meert, N.; Glorieux, G.; Temmar, M.; Choukroun, G.; Vanholder, R.; Massy, Z.A. Serum Indoxyl sulfate is associated with vascular disease and mortality in chronic kidney disease patients. Clin. J. Am. Soc. Nephrol. 2009, 4, 1551-1558. [CrossRef] [PubMed]

4. $\quad$ Bammens, B.; Evenepoel, P.; Keuleers, H.; Verbeke, K.; Vanrenterghem, Y. Free serum concentrations of the protein-bound retention solute p-cresol predict mortality in hemodialysis patients. Kidney Int. 2006, 69, 1081-1087. [CrossRef] [PubMed]

5. Duranton, F.; Cohen, G.; De Smet, R.; Rodriguez, M.; Jankowski, J.; Vanholder, R.; Argiles, A. Normal and pathologic concentrations of uremic toxins. J. Am. Soc. Nephrol. 2012, 23, 1258-1270. [CrossRef] [PubMed]

6. Itoh, Y.; Ezawa, A.; Kikuchi, K.; Tsuruta, Y.; Niwa, T. Protein-bound uremic toxins in hemodialysis patients measured by liquid chromatography/tandem mass spectrometry and their effects on endothelial ROS production. Anal. Bioanal. Chem. 2012, 403, 1841-1850. [CrossRef] [PubMed]

7. Deltombe, O.; de Loor, H.; Glorieux, G.; Dhondt, A.; Van Biesen, W.; Meijers, B.; Eloot, S. Exploring binding characteristics and the related competition of different protein-bound uremic toxins. Biochimie 2017, 139, 20-26. [CrossRef]

8. Ghuman, J.; Zunszain, P.A.; Petitpas, I.; Bhattacharya, A.A.; Otagiri, M.; Curry, S. Structural basis of the drug-binding specificity of human serum albumin. J. Mol. Biol. 2005, 353, 38-52. [CrossRef] [PubMed] 
9. Sakai, T.; Takadate, A.; Otagiri, M. Characterization of binding site of uremic toxins on human serum albumin. Biol. Pharm. Bull. 1995, 18, 1755-1761. [CrossRef] [PubMed]

10. Watanabe, H.; Noguchi, T.; Miyamoto, Y.; Kadowaki, D.; Kotani, S.; Nakajima, M.; Miyamura, S.; Ishima, Y.; Otagiri, M.; Maruyama, T. Interaction between two sulfate-conjugated uremic toxins, p-Cresyl sulfate and indoxyl sulfate, during binding with human serum albumin. Drug Metab. Dispos. 2012, 40, 1423-1428. [CrossRef] [PubMed]

11. Rabbani, G.; Ahmad, E.; Zaidi, N.; Khan, R.H. pH-dependent conformational transitions in conalbumin (ovotransferrin), a metalloproteinase from hen egg white. Cell Biochem. Biophys. 2011, 61, 551-560. [CrossRef] [PubMed]

12. Dockal, M.; Carter, D.C.; Rüker, F. Conformational transitions of the three recombinant domains of human serum albumin depending on pH. J. Biol. Chem. 2000, 275, 3042-3050. [CrossRef] [PubMed]

13. Tijink, M.S.; Wester, M.; Glorieux, G.; Gerritsen, K.G.; Sun, J.; Swart, P.C.; Borneman, Z.; Wessling, M.; Vanholder, R.; Joles, J.A.; et al. Mixed matrix hollow fiber membranes for removal of protein-bound toxins from human plasma. Biomaterials 2013, 34, 7819-7828. [CrossRef] [PubMed]

14. Yamamoto, S.; Kazama, J.J.; Omori, K.; Matsuo, K.; Takahashi, Y.; Kawamura, K.; Matsuto, T.; Watanabe, H.; Maruyama, T.; Narita, I. Continuous reduction of protein-bound uraemic toxins with improved oxidative stress by using the oral charcoal adsorbent AST-120 in haemodialysis patients. Sci. Rep. 2015, 5, 14381. [CrossRef] [PubMed]

15. Meyer, T.W.; Peattie, J.W.; Miller, J.D.; Dinh, D.C.; Recht, N.S.; Walther, J.L.; Hostetter, T.H. Increasing the clearance of proteinbound solutes by addition of a sorbent to the dialysate. J. Am. Soc. Nephrol. 2007, 18, 868-874. [CrossRef] [PubMed]

16. Meijers, B.K.; Bammens, B.; Verbeke, K.; Evenepoel, P. A Review of albumin binding in CKD. Am. J. Kidney Dis. 2008, 51, 839-850. [CrossRef] [PubMed]

17. Mingrone, G.; De Smet, R.; Greco, A.; Bertuzzi, A.; Gandolfi, A.; Ringoir, S.; Vanholder, R. Serum uremic toxins from patients with chronic renal failure displace the binding of 1-tryptophan to human serum albumin. Clin. Chim. Acta 1997, 260, 27-34. [CrossRef]

18. Meijers, B.K.; De Loor, H.; Bammens, B.; Verbeke, K.; Vanrenterghem, Y.; Evenepoel, P. p-Cresyl Sulfate and indoxyl sulfate in hemodialysis patients. Clin. J. Am. Soc. Nephrol. 2009, 4, 1932-1938. [CrossRef] [PubMed]

19. Al-Chalabi, A.; Matevossian, E.; von Thaden, A.; Schreiber, C.; Radermacher, P.; Huber, W.; Perez Ruiz de Garibay, A.; Kreymann, B. Evaluation of an advanced organ support (ADVOS) system in a two-hit porcine model of liver failure plus endotoxemia. Intensive Care Med. Exp. 2017, 5, 31. [CrossRef] [PubMed]

20. Kavita, U.; Duo, J.; Crawford, S.M.; Liu, R.; Valcin, J.; Gleason, C.; Dong, H.; Gadkari, S.; Dodge, R.W.; Pillutla, R.C.; et al. A systematic study of the effect of low $\mathrm{pH}$ acid treatment on anti-drug antibodies specific for a domain antibody therapeutic: Impact on drug tolerance, assay sensitivity and post-validation method assessment of ADA in clinical serum samples. J. Immunol. Methods 2017, 448, 91-104. [CrossRef] [PubMed] 